\begin{tabular}{|l|l|l||}
\hline \multicolumn{2}{|c|}{ PublisherInfo } \\
\hline \hline PublisherName & $:$ & BioMed Central \\
\hline \hline PublisherLocation & $:$ & London \\
\hline \hline PublisherImprintName & $:$ & BioMed Central \\
\hline \hline
\end{tabular}

\title{
Drug-Induced Lung Diseases
}

\begin{tabular}{|l|c|l||}
\hline \multicolumn{2}{|c|}{ ArticleInfo } \\
\hline \hline ArticleID & $:$ & 4288 \\
\hline \hline ArticleDOI & $:$ & $10.1186 /$ ccf-2000-webreport1603 \\
\hline \hline ArticleCitationID & $:$ & webreport1603 \\
\hline \hline ArticleSequenceNumber & $:$ & 29 \\
\hline \hline ArticleCategory & $:$ & Web report \\
\hline \hline ArticleFirstPage & $:$ & 1 \\
\hline \hline ArticleLastPage & $:$ & 3 \\
\hline \hline & & RegistrationDate : 2000-8-22 \\
\hline ArticleHistory & $:$ & OnlineDate \\
\hline \hline ArticleCopyright & $:$ & Current Science Ltd2000-8-22 \\
\hline \hline ArticleGrants & $:$ & \\
\hline \hline ArticleContext & $:$ & 1305444 \\
\hline \hline
\end{tabular}




\section{Overview}

The site, available in both English and French, was created by the Department of Pulmonary Diseases and Intensive Care Unit in Dijon, France and offers up-to-date information about a growing number of drug-induced lung diseases. There are two ways of accessing data; either by searching through an alphabetically-ordered list of generic drug names, or by looking through a list of clinical or radiological patterns of involvement of the respiratory system. Whichever way you choose, you are led to a list of research articles pertinent to the drug and the form(s) of lung disease it induces. In addition, each drug is given a star-rating according to the weight of evidence that supports a role for it as a causative factor in respiratory disease. One star indicates an isolated case reported in the literature and four stars indicates more than 100 reported cases. The site also invites readers to submit their own personal case reports.

\section{Content}

The site is small and simple to navigate and is an effective quick reference guide. The information it provides is very basic however, and it would be necessary to go and look-up the research articles it suggests, if you wanted more detailed information.

\section{Other comments}

09-Jul-2000

\section{Evaluation}

None 


\section{References}

1. Pneumotox Online. [http://www.pneumotox.com/index.html\#return0]

This PDF file was created after publication. 